\section{A comparative study of the effects of high pressure on proteolytic degradation of sardine and blue whiting muscle}

\author{
ARANZAZU HERNÁNDEZ-ANDRÉS, MIRIAM \\ PÉREZ-MATEOS,* PILAR MONTERO AND MARIA \\ DEL CARMEN GÓMEZ-GUILLÉN
}

Instituto del Frío (CSIC), José Antonio Novais 10, 28040

Madrid, Spain

\begin{abstract}
High-pressure technology is used as an alternative to heat processing because of its inactivating effect on microorganisms and enzymes. However, it can also alter the structure of other muscle proteins. The present study compares the effects of high pressure $\left(300 \mathrm{MPa}, 7^{\circ} \mathrm{C}\right.$, $20 \mathrm{~min}$ ) on the proteolytic degradation and alterations in the myofibrillar proteins of sardine and blue whiting muscle. Also, muscle homogenates and enzyme extracts were pressurized in order to evaluate the high-pressure effects on unprotected proteolytic enzymes outside the whole muscle structure. Peak proteolytic activity was found to occur at $55^{\circ} \mathrm{C}$ in both species. The peak activity $\mathrm{pH}$ was $\mathrm{pH} 3$ for the sardine and $\mathrm{pH} 8$ for the blue whiting; the main enzyme families being aspartic proteases in the former and alkaline serine proteases in the latter. Pressurization lowered activity levels at the peak activity $\mathrm{pH}$ and temperature in the fish muscle (by $30.8 \%$ in the sardine and by $9.5 \%$ in the blue whiting) and also slightly in the enzyme extracts (by $16.8 \%$ in the sardine and by $19.4 \%$ in the blue whiting). The electrophoretic profiles disclosed higher protein degradation in the pressurized muscle. Overall, the observed changes in proteolytic activity can be attributed not only to the effect of high pressure on the enzymes, but also and mainly, to the effect on other muscle proteins.
\end{abstract}

KEY WORDS: enzymes, high pressure, muscle, myofibrillar proteins, proteolytic

\section{INTRODUCTION}

Enzymatic activity plays a particularly important role in post-mortem degradation in fish muscle tissue. Lysosomal cathepsins and calpains are regarded as the major groups responsible for post-mortem changes in fish muscle texture, ${ }^{1}$ but metalloproteases are also involved. ${ }^{2}$ Proteases also play an important role in the degradation of myofibrillar proteins and may affect the suitability of the muscle for technological processing. For instance, proteases can hinder traditional heat-induced gelation, a process which may vary considerably according to species and attributable to, among other factors, the action of heat-stable, myosin-degrading. ${ }^{3-5}$

It therefore follows that regulating enzymatic activity should help maintain or improve product quality and shelf life. A number of methods of inhibiting the action of muscle proteases have been employed, for example, washing the muscle, adding food-grade inhibitors, ${ }^{6}$ and using fast heating methods such as ohmic heating ${ }^{7}$ or microwaving. ${ }^{8}$ High hydrostatic pressure technology has gained popularity as an alternative to heat processing for use as a food processing tool in controlling microbial activity and altering proteins, enzymes and other food macromolecules. The literature dealing with changes in proteolytic activity in fish muscle indicates that the effects of high pressure depends on the species concerned, and the duration, temperature and degree of pressurization, the $\mathrm{pH}$, and enzyme. ${ }^{9-11}$

There has been ongoing disagreement as to whether high pressure in fact activates or inactivates muscle enzymes. Leaving aside possible differences due to enzyme type and processing conditions, the pattern of enzymatic activity appears to differ according to whether studies are conducted on extracts or on actual muscle tissue. In extracts, enzymes are unprotected, and for that reason intramolecular changes in enzyme structure/conformation are the main cause of pressure-induced inactivation. However, pressurization of the muscle entails changes in the conformation of the myofibrillar proteins, thereby influencing the specificity of the enzyme/substrate interaction, and disrupts cell membranes, releasing enzymes, which may in turn increase proteolytic activity, depending on the level of pressure employed. Simpson ${ }^{12}$ compared residual activity in enzyme extracts from pressurized fish muscle and in pressurized enzyme extracts from non-pressurized muscle, and found the extent of inactivation of the proteases to be generally higher in the enzyme extracts from the pressurized tissue. The explanation posited was that other components naturally present in the intact fish tissue may act in concert with pressure to bring about greater inactivation of the enzymes. Conversely, Lakshmanan et al. ${ }^{13}$ reported that the effect of high pressure on proteolytic activity was lower in pressurized cold-smoked salmon muscle than in pressurized enzyme extracts, suggesting that enzymes are more resistant to pressure in the muscle tissue.

Sardine and blue whiting are two small fish species, the former being a fatty species, the latter a lean species. Both species spoil rapidly and are undervalued and underused. In these circumstances, using high pressure to inactivate 
proteolytic enzymes could enhance shelf life, while at the same time producing alterations in muscle proteins which could improve the usefulness of these species in processing restructured seafood products, thereby upgrading their marketability. The object of this study was to determine the effects of high pressure on proteolytic enzymes in sardine and blue whiting muscle, and to assess alterations in the myofibrillar proteins. These aspects offer interest to understanding the degradation in protein quality taking place during product shelf life, as well as the suitability of pressurized raw muscle for processing.

\section{MATERIALS AND METHODS}

\section{Sample preparation and treatment}

Sardine Sardina pilchardus and blue whiting Micromesistius poutassou were purchased at a local market, within $24-48 \mathrm{~h}$ of capture, and transported in ice to the laboratory. Mean individual weight and length were $(89.8 \pm 9.1) \mathrm{g} \mathrm{/}(17.9 \pm 0.8) \mathrm{cm}$ for the sardine and $(68.1 \pm 10.0) \mathrm{g} /(19.7 \pm 1.0) \mathrm{cm}$ for the blue whiting.

\section{Muscle samples}

The muscle samples were prepared and pressurized as described in Hernández-Andres et al. ${ }^{14}$ The fish were gutted and washed immediately upon arrival and vacuum packed in flexible bags (Cryovac BB4L, Barcelona, Spain). Half of the vacuum-packed units were subjected to pressurization at $300 \mathrm{MPa}$ at $7^{\circ} \mathrm{C}$ for $20 \mathrm{~min}$ (pressurized batch: P), while the other half were held unpressurized (atmospheric pressure) at $7^{\circ} \mathrm{C}$ (non-pressurized batch: NP). Pressurization conditions were selected based on the results of previous enzyme inactivation assays, seeking the least possible alteration of the muscle with a view to further technological processing. ${ }^{9,12,15,16}$ Pressurization was carried out in a pilot high-pressure unit (ACB 665; Gec Alsthom, Nantes, France), where the temperature of the immersion medium (distilled water) was regulated by a thermocouple and programmed thermostating equipment (model IA/2230 AC; INMASA, Barcelona, Spain). Pressure was increased at $2.5 \mathrm{MPa} / \mathrm{s}$.

Pressurized and non-pressurized muscle samples were then frozen in an air-blast tunnel freezer (AGA-Frigoscandia 0-6373, Helsingborg, Sweden) at $-30^{\circ} \mathrm{C}$ for $2 \mathrm{~h}$. For each batch, the frozen fish were skinned and chopped into small pieces, and the pieces were all mixed together. The sample material was then again bagged as before, that is, vacuum packed in flexible bags, and stored for later analysis at $-54^{\circ} \mathrm{C}$ to minimize any alterations during storage.

The $\mathrm{pH}$ readings for muscle (1:10 [muscle : water]) were taken as described by Vyncke. ${ }^{17}$ The $\mathrm{pH}$ of the nonpressurized and pressurized muscle was, respectively, $6.09 \pm 0.01$ and $6.19 \pm 0.03$ in the sardine and $6.98 \pm 0.03$ and $7.03 \pm 0.06$ in the blue whiting.

\section{Homogenate samples}

Homogenates were prepared and pressurized as described in
Hernández-Andres et al. ${ }^{14}$ The homogenates were obtained from sardine chopped muscle (1:3 [muscle : buffer]) and from blue whiting chopped muscle (1:2 [muscle : buffer]) at the peak activity $\mathrm{pH}$ ( $\mathrm{pH} 3$ for the sardine and $\mathrm{pH} 6$ for the blue whiting) and at muscle $\mathrm{pH}$ ( $\mathrm{pH} 8$ for the sardine and $\mathrm{pH} 7$ for the blue whiting). The chopped muscle was homogenized in cold buffer at 10000 r.p.m. for $1 \mathrm{~min}$ in an iced-water bath, using an Omnimixer (Model ES-231, Homogenizer; Omni International, Waterbury, USA). The homogenates were filtered through four layers of cheesecloth in order to remove connective tissue. The homogenization buffers were McIlvaine buffer $(0.2 \mathrm{M}$ sodium phosphate, $0.1 \mathrm{M}$ sodium citrate) for acid $\mathrm{pH} ; 0.2 \mathrm{M}$ phosphate buffer for $\mathrm{pH} 6$ and 7; and $0.2 \mathrm{M}$ Tris- $\mathrm{HCl}$ for alkaline $\mathrm{pH}$. Half of homogenates (for each species and $\mathrm{pH}$ ) were pressurized (P: $300 \mathrm{MPa}$ at $7^{\circ} \mathrm{C}$ for $20 \mathrm{~min}$ ), while the other half were held without pressurization (NP: atmospheric pressure at $7^{\circ} \mathrm{C}$ ). Pressurized and nonpressurized homogenates were stored at $-80^{\circ} \mathrm{C}$ prior to analysis.

\section{Enzyme extracts}

The enzyme extracts were obtained as described by Lakshmanan et al. ${ }^{13}$ Chopped muscle (10 g) was homogenized with $50 \mathrm{~mL}$ ice-cold double-distilled water for $2 \mathrm{~min}$ and the homogenate allowed to stand in ice for 30min with occasional stirring. After $30 \mathrm{~min}$, the homogenate was centrifuged at $14600 \times g$ at $4^{\circ} \mathrm{C}$ for $20 \mathrm{~min}$. The supernatant was then filtered through a $0.45 \mu \mathrm{m}$ sterile filter unit (Sartorious 11306-090 G; Filtros Anoia, S.A., Barcelona, Spain). Half of all the extracts were pressurized (P: $300 \mathrm{MPa}$ at $7^{\circ} \mathrm{C}$ for $20 \mathrm{~min}$ ), while the other half were held without pressurization (NP: atmospheric pressure at $7^{\circ} \mathrm{C}$ ). Enzymes extracts were stored at $-80^{\circ} \mathrm{C}$ prior to analysis.

\section{Determination of proteolytic activity}

Proteolytic activity in the muscle and homogenates was determined according to the method described by Hernández-Andrés et al. ${ }^{14}$ For the enzyme extracts, proteolytic activity was assayed using the method of Lakshmanan et al., ${ }^{13}$ with incubation in a $5 \%(\mathrm{w} / \mathrm{v})$ hemoglobin solution for $1 \mathrm{~h}$. In all cases, proteolytic activity has been expressed as $\mu$ moles of tyrosine released per gram of muscle per hour of incubation ( $\mu \mathrm{mol} \mathrm{Tyr} / \mathrm{g} / \mathrm{h})$.

First, the effect of temperature $\left(20-80^{\circ} \mathrm{C}\right)$ on proteolytic activity in the muscle was examined at muscle pH. Next, proteolytic activity was assayed over a range of $\mathrm{pH}$ values, that is, $\mathrm{pH} 2.5-8$ at 40 and $55^{\circ} \mathrm{C}$ in the sardine muscle and $\mathrm{pH} 3-10$ at $55^{\circ} \mathrm{C}$ in the blue whiting muscle. For this assay, homogenates were prepared at each experimental $\mathrm{pH}$ using the buffers described above. The conditions of optimum proteolytic activity in the muscle were known from the results of this study. Proteolytic activity in the homogenates and enzyme extracts of both species was determined at muscle $\mathrm{pH}$ and at the peak activity $\mathrm{pH}$ at $55^{\circ} \mathrm{C}$. These $\mathrm{pH}$ and temperature conditions were chosen in order to ascertain how high pressure affected proteolytic activity, since under these conditions of muscle $\mathrm{pH}$ and peak activity $\mathrm{pH}$, 
changes brought about by high pressure processing should be more appreciable at the maximum temperature.

\section{Sample preparation for electrophoresis/sodium dodecylsulfate-polyacrylamide gel electrophoresis}

An amount of $1 \mathrm{~g}$ of muscle was first incubated in a water bath at $40^{\circ} \mathrm{C}$ or $55^{\circ} \mathrm{C}$ for 0,4 or $8 \mathrm{~h}$, and held at $7^{\circ} \mathrm{C}$ for 0,8 or $24 \mathrm{~h}$. The electrophoresis sample was then prepared according to the method described by Hernández-Andrés et al. ${ }^{14}$

For the homogenates, proteins were precipitated with $10 \%$ trichloroacetic acid (TCA) in a proportion of $1: 3(\mathrm{v} / \mathrm{v})$ before and after incubation at $55^{\circ} \mathrm{C}$ for $1 \mathrm{~h}$, and the TCAsoluble peptide composition was determined.

The denaturing sodium dodecylsulfate-polyacrylamide gel electrophoresis (SDS-PAGE) sample buffer for the proteins from the muscle or the homogenates of both species was $25 \%(\mathrm{v} / \mathrm{v}) \quad \beta$-mercaptoethanol, $12.5 \%(\mathrm{w} / \mathrm{v})$ SDS, $50 \mathrm{mM}$ Tris-HCl, $5 \mathrm{mM}$ ethylenediaminetetraacetic acid (EDTA), 10\% (w/v) glycerin, and 0.01\% (w/v) bromophenol blue (PANREAC). Buffer composition for the enzyme extracts was the same, except no $\beta$-mercaptoethanol was used. Electrophoresis SDS-PAGE (10\%) was carried out in the conditions described by Hernández-Andrés et al. ${ }^{14}$ An amount of $30 \mu \mathrm{g}$ of protein was loaded per lane for both the muscle and the enzyme extracts. Table 1 sets out the protein content of the homogenates for electrophoresis.

\section{Inhibition of proteolytic muscle enzymes}

The assay was performed according to Hernández-Andrés et al. ${ }^{14}$ The following inhibitors were tested to classify the proteinases in the muscle: $1 \mathrm{mM}$ iodoacetic acid (IA), as a cysteine protease inhibitor; $1 \mathrm{mg} / \mathrm{mL}$ phenylmethyl sulfonyl fluoride (PMSF), as a serine protease inhibitor; $0.2 \mu \mathrm{g} / \mathrm{mL}$ pepstatin A (Peps. A), as an aspartic protease inhibitor; and $10 \mathrm{mM}$ (EDTA), as a metalloprotease inhibitor. All the inhibitors used were from Sigma Chemical (St. Louis, MO, USA). The assay conditions were $\mathrm{pH} 3$ and $\mathrm{pH} 6$ at $55^{\circ} \mathrm{C}$ for the sardine and $\mathrm{pH} 7$ and $\mathrm{pH} 8$ at $55^{\circ} \mathrm{C}$ for the blue whiting, these being the optimum $\mathrm{pH}$ and temperature conditions to maximize enzyme activity.

\section{Determination of cathepsin D-like activity in the blue whiting muscle}

The determination was carried out according to the method described by Gómez-Guillén and Batista ${ }^{18}$ at $\mathrm{pH} 3$ and pH 7 at $55^{\circ} \mathrm{C}$ for $1 \mathrm{~h}$. The reaction was stopped with $10 \%(\mathrm{w} / \mathrm{v})$ trichloroacetic acid (TCA) in a proportion of $1: 1(\mathrm{v} / \mathrm{v})$. The test tubes were then held at $4^{\circ} \mathrm{C}$ for $15 \mathrm{~min}$ to allow precipitation of unhydrolyzed proteins and centrifuged (MicroSpin 24S, Sorvall Instruments, DuPont, Wilmington, DE, USA) at $5700 \times g$ at $4^{\circ} \mathrm{C}$ for $15 \mathrm{~min}$. The results have been expressed as $\mu$ moles of tyrosine equivalent released from bovine Hb per gram of muscle per hour.

\section{Statistical analysis}

Statistical analysis was carried out separately for each species. Analysis of variance (ANOVA) was performed using the SPSS computer program (version 11.5; SPSS Inc., Chicago, IL, USA). Pairs of mean values were compared using the Bonferroni test, Tamhane test, or Tukey's test, depending on the homogeneity of the variance, with the significance level set at $P \leq 0.05$. A $t$-test was used to compare the differences between the means for variables that discriminated between groups.

\section{RESULTS AND DISCUSSION}

\section{Influence of high-pressure processing of fish muscle on protease activity}

The effect of temperature and $\mathrm{pH}$ were evaluated to establish the influence of high-pressure processing of fish muscle on protease activity. Proteolysis activity, expressed as $\mu \mathrm{mol} \mathrm{Tyr} / \mathrm{g} / \mathrm{h}$, was considerably higher in the blue whiting muscle than in the sardine muscle, especially at the peak activity temperature of $50-60^{\circ} \mathrm{C}$ (Fig. 1a). Pressurization appreciably increased $(P \leq 0.05)$ the proteolysis values for the blue whiting muscle at temperatures below the peak activity temperature. In contrast, pressurized sardine muscle exhibited a significant decrease at the peak activity temperature $\left(55-60^{\circ} \mathrm{C}\right)$. Hernández-Andrés et al. ${ }^{14}$ reported that pressurization in the same conditions as those used in the present study significantly increased enzymatic activity in squid Todaropsis eblanae mantle muscle at $35-40^{\circ} \mathrm{C}$ and at 55 $60^{\circ} \mathrm{C}$.

The effect of incubation at different $\mathrm{pH}$ levels on proteolytic activity was studied at $55^{\circ} \mathrm{C}$, the peak activity temperature for both species. Proteolysis values in the blue whiting muscle peaked at $\mathrm{pH}$ 8-9, substantially higher than in the sardine (Fig. 1b). The sardine muscle, by contrast, displayed higher values under acid conditions, with activity values peaking at $\mathrm{pH} 3$, probably a consequence of cathepsin D-like activity. ${ }^{18}$ In general, high-pressure processing did not significantly alter the proteolytic activity curve with $\mathrm{pH}$ in the blue whiting muscle, although slight differences $(P \leq 0.05)$ were observable over the range of peak activity (Fig. 1b). Angsupanich and Ledward ${ }^{15}$ reported three activity peaks in cod, the highest at $\mathrm{pH}$ 6.6, the next at $\mathrm{pH} 9.0$ and the last at $\mathrm{pH}$ 3.3. The differing profile with respect to blue whiting is probably due to interspecific differences, even though both species belong to the same family, Gadidae. In the sardine muscle, pressurization caused a significant reduction $(P \leq 0.05)$ in proteolytic activity at acid $\mathrm{pH}$ levels. The effect of pressurization on proteolytic activity in the sardine muscle at different $\mathrm{pH}$ values was also tested at a lower temperature $\left(40^{\circ} \mathrm{C}\right.$ ) (data not shown), because as illustrated in Figure 1a, the differences with respect to the values recorded at $55^{\circ} \mathrm{C}$ were not as large as those observed in the blue whiting. The curves for proteolytic activity in both the pressurized and non-pressurized batches of sardine muscle on $\mathrm{pH}$ at $40^{\circ} \mathrm{C}$ were similar to the curves at $55^{\circ} \mathrm{C}$, though values were somewhat lower. As in the case of the sardine muscle, the 
$\mathrm{pH}$ for peak proteolytic activity in pressurized squid Todaropsis eblanae mantle (300 $\left.\mathrm{MPa}, 7^{\circ} \mathrm{C}, 20 \mathrm{~min}\right)$ was also acidic, and pressure likewise did not alter the $\mathrm{pH} .{ }^{14}$

\section{Influence of high-pressure processing on fish muscle protease}

In order to determine the influence of high-pressure processing on enzymatic activity in the fish muscle, the enzyme families were identified by adding specific protease inhibitors under both natural post-mortem $\mathrm{pH}$ conditions as well as peak activity conditions in order to intensify the effects.

Figure 2 depicts the effects of specific enzyme inhibitors on proteolytic activity in the sardine and blue whiting muscle at $55^{\circ} \mathrm{C}$ at different $\mathrm{pH}$ values, namely, the peak activity level in both species and also the natural postmortem $\mathrm{pH}$ (pH 6 in the sardine, $\mathrm{pH} 7$ in the blue whiting). At the natural post-mortem $\mathrm{pH}$ (Fig. 2a), the high degree of inhibition of proteolytic activity (low residual activity), achieved by PMSF and pepstatin A, suggests that serine and aspartic proteases predominated at the peak activity temperature $\left(55^{\circ} \mathrm{C}\right)$. In the non-pressurized batches, inhibition by pepstatin A was significantly higher in the sardine muscle than in the blue whiting, as was to be expected from the activity curves with $\mathrm{pH}$ for both species (Fig. 1b). In the sardine muscle, no significant differences in serine protease activity were observed after high-pressure processing, but aspartic protease activity was lower (higher residual activity) in the pressurized batch $(P \leq 0.05)$. The behavior of the serine and aspartic protease populations in the blue whiting muscle differed from that in the sardine muscle, with lower residual activity levels being observed for both these enzyme populations following pressurization.

Cysteine proteases inhibited by iodoacetic acid were partially activated by high pressure in the sardine muscle, in opposition to what happened in the pressurized blue whiting muscle, in which residual activity levels remained higher than in the non-pressurized batch. These neutral cysteine proteases, partially inactivated by high pressure, were probably calpains, cytoplasmic cysteine proteases with peak enzymatic activity at pH 7 sensitive to high pressures. ${ }^{19}$ The above-mentioned pressure-induced increase in cysteine protease activity in the sardine muscle could be explained by the release of enzymes from the lysosomes, that is, high pressure would appear to break down the lysosome membranes, resulting in leakage of the lysosomal enzymes. $^{20-22}$ Chéret et al. ${ }^{23}$ showed that high-pressure processing up to $500 \mathrm{MPa}\left(5 \mathrm{~min},<10^{\circ} \mathrm{C}\right)$ increased cysteine protease (cathepsins $\mathrm{B}, \mathrm{H}, \mathrm{L}$ ) activity in sea bass Dicentrarchus labrax fillets, whereas cathepsin D-like activity increased up to $300 \mathrm{MPa}$.

Inhibition of the neutral metalloproteases by EDTA showed the contribution of these enzymes to be slight, perceptible only in the case of the sardine muscle. The metalloproteases were unaffected by high-pressure processing.

Incubation with pepstatin $\mathrm{A}$ at the peak activity $\mathrm{pH}$ for the sardine $(\mathrm{pH} 3)$ yielded complete inactivation in both the pressurized and non-pressurized batches (Fig. 2b). This result is indicative of the predominance of aspartic proteases, with cathepsin $\mathrm{D}$ being the main lysosomal pepstatin-sensitive aspartic protease involved in the degradation of cell proteins. Gómez-Guillén and Batista ${ }^{18}$ reported a peak activity $\mathrm{pH}$ of 3.2 and a peak activity temperature of $55^{\circ} \mathrm{C}$ for cathepsin D-like activity in sardine muscle. It therefore seems likely that the peak proteolytic activity recorded at $\mathrm{pH} 3 / 55^{\circ} \mathrm{C}$ in this study should be ascribable to the presence of this enzyme. The high degree of inhibition achieved by PMSF and iodoacetic acid denoted significant contributions to proteolytic activity by acid serine and cysteine proteases in the sardine muscle. Proteolytic activity by these two families of proteases increased slightly upon pressurization.

Incubation at the peak activity $\mathrm{pH}$ for the blue whiting (pH 8) did not test pepstatin A as an inhibitor (Fig. 2c). Alkaline serine proteases were the main family of enzymes involved in muscle proteolysis and were activated slightly by high pressure. No significant contributions by cysteine proteases or by metalloproteases were recorded in either of the two batches (pressurized and non-pressurized) in these experimental conditions.

According to the present findings, aspartic and serine proteases predominated in both the sardine and the blue whiting muscle, and were affected differently by pressurization. In squid mantle, ${ }^{14}$ in contrast, acid cysteine proteases and to lesser extent acid serine proteases, were the principal enzymes present and the main enzymes affected by high pressure.

The assay performed using specific enzyme inhibitors at $\mathrm{pH} 7$ at $55^{\circ} \mathrm{C}$ in blue whiting muscle (Fig. 2a) resulted in strong inhibition of aspartic protease activity by pepstatin A. In view of this finding, it was decided to examine cathepsin D-like activity at $\mathrm{pH} 7$ as well as at $\mathrm{pH} 3$, within the range of peak activity for cathepsin D-like enzymatic activity. ${ }^{18,24}$ The assay was carried out at $55^{\circ} \mathrm{C}$, the same temperature used previously for the specific inhibitor assay. Cathepsin D-like activity $(0.07 \mu \mathrm{mol} \mathrm{Tyr} / \mathrm{g} / \mathrm{h})$ was recorded for batch $\mathrm{NP}$ at $\mathrm{pH} 7$, but a higher value $(0.16 \mu \mathrm{mol} \mathrm{Tyr} / \mathrm{g} / \mathrm{h})$ was recorded for the batch $\mathrm{P}$. As was to be expected, activity levels were higher at the peak activity $\mathrm{pH}(\mathrm{pH} 3)$, and again the value was higher for batch P (NP: $0.22 \mu \mathrm{mol}$ Tyr/g/h; P: $0.39 \mu \mathrm{mol} \mathrm{Tyr} / \mathrm{g} / \mathrm{h})$. The higher activity rate brought about by the effects of pressurization might be attributable to the release of lysosomal enzymes. ${ }^{20-22}$ Kubo et al. ${ }^{25}$ subjected rabbit muscle to high pressures (100-400 MPa, $5 \mathrm{~min}$, chilled temperature) and showed that $100 \mathrm{MPa}$ sufficed to alter lysosome shape, and that the release of cathepsin D from the lysosomes intensified as pressure increased; after release, the cathepsin $\mathrm{D}$ was absorbed by the myofibrils.

\section{Influence of high-pressure treatment on myofibrillar proteins at chilled storage and fish cooking/processing}

Basically, what was being studied here was the effect of high pressure on enzymes, and this may involve an effect on muscle proteins, both as a result of direct action by pressure 
and by enzymatic activity following pressurization.

The influence of enzymes and/or high pressure on muscle proteins (aggregation and proteolysis) at chilled storage was therefore examined using the electrophoretic profile. The pressurized muscle was held at $7^{\circ} \mathrm{C}$ (chilled storage temperature) for 0,8 , or $24 \mathrm{~h}$ (Fig. 3 ) in order to study the proteolytic degradation taking place under the actual conditions of chilled-fish storage. The results showed that the myosin heavy chain (MHC) band gradually faded with the time of incubation in the sardine batch P (Fig. 3a), and slightly after $24 \mathrm{~h}$ in the control bath. Actin (Ac) was hydrolyzed only in batch $\mathrm{P}$, the breakdown being more apparent after $24 \mathrm{~h}$. However, in the blue whiting muscle (Fig. 3b), no appreciable proteolysis took place at this temperature over the 24-h study period in batch P. Similarly, Angsupanich and Ledward ${ }^{15}$ recorded no changes in the electrophoretic patterns for pressurized and non-pressurized cod refrigerated at $4^{\circ} \mathrm{C}$ for 7 days.

In general, Ac was more susceptible to proteolysis in the pressurized batches, primarily in the sardine. In a study using differential scanning calorimetry, Fernández-Martín et al. $^{26}$ also reported different behavior of batches of blue whiting muscle homogenate with $\mathrm{NaCl}$ following pressurization at $7^{\circ} \mathrm{C}$, attributed to unfolding of the Ac.

Furthermore, the influence of enzymes and/or high pressure on muscle proteins (aggregation and proteolysis) on cooking or later thermal processing was also determined by the electrophoretic profile in order to evaluate the final quality of the fish protein. The pressurized muscle was held at $40^{\circ} \mathrm{C}$ and $55^{\circ} \mathrm{C}$ for 0,4 or $8 \mathrm{~h}$. Figures 4 and 5 show the protein composition of the non-pressurized and pressurized sardine (Fig. 4) and blue whiting (Fig. 5) muscle incubated at $40^{\circ} \mathrm{C}$ and at $55^{\circ} \mathrm{C}$ for 0,4 and $8 \mathrm{~h}$. The main bands observable at $0 \mathrm{~h}$ were, in all cases, MHC and Ac. Other bands between 45 and $15 \mathrm{kDa}$ were different troponins, tropomyosin and myosin light chains, along with sarcoplasmic proteins. The electrophoretic profiles for the non-pressurized sardine muscle were the same after incubation at $40^{\circ} \mathrm{C}$ for $4 \mathrm{~h}$ and $8 \mathrm{~h}$ (Fig. 4a). The MHC band was slightly visible after incubation for $8 \mathrm{~h}$. In contrast, in batch $\mathrm{P}$, the MHC had undergone complete proteolysis after $8 \mathrm{~h}$ and was not visible. Incubation at $55^{\circ} \mathrm{C}$ yielded a similar profile (Fig. 4b). The lower proteolytic activity values for batch $\mathrm{P}$ at temperatures ranging from $40^{\circ} \mathrm{C}$ to $80^{\circ} \mathrm{C}$, described in previous sections (Fig. 1a), which were incubated during $1 \mathrm{~h}$, were not visible in the SDS-PAGE results, very likely because of the heat stability of the enzymes involved (with enzymatic activity peaking at around $55^{\circ} \mathrm{C}$ ) and because of the time-dependent nature of the degradation of the myofibrillar proteins by endogenous proteinases. Ac was only slightly affected by pressurization after incubation at $40^{\circ} \mathrm{C}$ for $4 \mathrm{~h}$ and $8 \mathrm{~h}$; at $55^{\circ} \mathrm{C}$, it was unaltered in both batches, probably due to inactivation, at high temperatures, of the enzymes involved in Ac degradation.

The MHC band grew fainter with incubation time in the non-pressurized blue whiting muscle incubated at $40^{\circ} \mathrm{C}$ (Fig. 5a), and ceased to be visible after $8 \mathrm{~h}$. Degradation was faster in batch $\mathrm{P}$, and the MHC band ceased to be observable after incubation for $4 \mathrm{~h}$. Bands resulting from MHC breakdown (with weights between 220 and $97 \mathrm{kDa}$ ) did not disappear in batch $\mathrm{P}$ with incubation time. Ac was only slightly affected in the pressurized batch after incubation for 4-8 h.

The electrophoretic patterns for the two blue whiting batches at the incubation temperature of $55^{\circ} \mathrm{C}$ are shown in Figure 5b. Heavy proteolysis of the MHC, leading to the appearance of MHC breakdown bands, took place in both batches after incubation for $4 \mathrm{~h}$. In this connection, high degradation of myofibrillar proteins, in particular myosin, by heat-stable alkaline serine proteases has previously been described. ${ }^{5,27}$ Upon pressurization, numerous high-intensity MHC degradation bands appeared after incubation for 4 and $8 \mathrm{~h}$, as was also observed at $40^{\circ} \mathrm{C}$ (Fig. 5a). Ac was slightly affected at $55^{\circ} \mathrm{C}$, though less than at $40^{\circ} \mathrm{C}$.

\section{Influence of high-pressure processing on muscle protein specificity as a protease substrate}

The first part of this article dealt with the effect of pressure on the enzymes in whole or minced muscle, but it should be borne in mind that in certain processes (e.g. gelation), the muscle completely disintegrates, releasing the content of cell organelles into the surrounding medium. These organelles include lysosomes, which collect large quantities of proteolytic enzymes. Therefore, assays were carried out using homogenates to evaluate the effect of pressure in conditions in which the muscle has been homogenized and consequently there is greater enzyme availability. As further shown, these assays were intended to gauge extant levels of autolysis, that is, enzymatic activity in homogenates containing muscle proteins and muscle enzymes at actual muscle $\mathrm{pH}$ and at peak activity $\mathrm{pH}$, though to speed up the process the assays were carried out at optimum temperature in both cases. Extracts were also prepared. That is, after the muscle had been homogenized, most of the myofibrillar proteins were removed, leaving behind mainly enzymes, in order to assess the stability of the enzymes (enzymatic activity) when they were unprotected from the surrounding medium.

Table 2 summarizes the results of proteolytic activity at $55^{\circ} \mathrm{C}$ for pressurized and non-pressurized homogenates, and extracts from sardine and blue whiting muscle at the natural post-mortem muscle $\mathrm{pH}$ ( $\mathrm{pH} 6$ in the sardine; $\mathrm{pH} 7$ in the blue whiting), and also at the peak activity $\mathrm{pH}(\mathrm{pH} 3$ in the sardine; $\mathrm{pH} 8$ in the blue whiting). Pressurization of the sardine muscle homogenates sharply increased proteolysis at the two $\mathrm{pH}$ levels tested as compared to the non-pressurized homogenates (Table 2). This was probably caused by greater accessibility of the proteins acting as substrates, ensuing from structural changes brought about by pressurization as well as by disruption of lysosomal membranes and the resulting release of enzymes. However, direct pressurization of the enzyme extracts, with their low contents of both myofibrillar proteins and other cell structures, reduced proteolytic activity only very slightly at both $\mathrm{pH} 6$ and $\mathrm{pH} 3$, suggesting that the enzymes were quite resistant to pressure. 
The behavior of the pressurized blue whiting homogenates was the converse of that of the sardine, that is, proteolytic activity declined $(P \leq 0.05)$ after pressurization at both $\mathrm{pH}$ levels tested ( $\mathrm{pH} 7$ and 8). Therefore, there seemed to be no apparent contribution of lysosomal leakage to global proteolytic activity values in the pressurized blue whiting homogenates. Proteolytic activity in the pressurized blue whiting extracts decreased very slightly at $\mathrm{pH} 8$, as was observed for the sardine extracts, whereas activity at $\mathrm{pH} 7$ was practically unchanged.

The results of electrophoresis of the TCA-soluble peptides in the sardine and blue whiting homogenates, before and after incubation at $55^{\circ} \mathrm{C}$ for $1 \mathrm{~h}$, are depicted in Figure 6. A combination of faded bands and an accumulation of low-molecular-weight proteins (Fig. 6a), probably caused by a conjunction of protein rupture and aggregation, was observed after pressurization of the sardine homogenate at $\mathrm{pH} 6$. A clearer increase in low-molecularweight bands, with a concomitant loss of higher-molecularweight bands, was observed in batch $\mathrm{P}$ after incubation at $55^{\circ} \mathrm{C}$ for $1 \mathrm{~h}$. This was probably related to increased proteolytic activity after pressurization at pH 6 (Table 2).

The electrophoretic profiles for the sardine homogenate at pH 3 (Fig. 6b) generally had fewer bands than the profiles obtained at $\mathrm{pH} 6$ as a result of the protein aggregating effect exerted by the acid $\mathrm{pH}$. Pressurization led to an increase in the number of high and, especially, low-molecular-weight proteins (Fig. 6) and was associated with an increase in the concentration of TCA-soluble peptides (Table 3). This finding could suggest that the appreciable pressure-induced rupture of proteins occurred, outweighed the aggregating effect. Furthermore, compared to the unincubated batches, incubation at $55^{\circ} \mathrm{C}$ resulted in a larger accumulation of breakdown peptides in the pressurized homogenate than in the non-pressurized homogenate, as a result of the higher level of proteolysis described in Table 2.

Various bands disappeared or grew fainter in the blue whiting homogenate at $\mathrm{pH} 7$ (Fig. 6c), but unlike the case of the sardine, this was not accompanied by an increase in breakdown peptides. Instead, there was a decline in TCAsoluble peptides after pressurization (Table 3), hence it follows that protein aggregation brought about by the highpressure processing was the predominant effect in this case. When the homogenates were incubated, protein degradation was again distinctly discernible and was more pronounced in batch P. Pressurizing the homogenate at $\mathrm{pH} 8$ (Fig. 6d) altered the electrophoretic profile drastically, with no medium and high-molecular-weight bands being present, and again without any concomitant increase in lowmolecular-weight peptides to speak of. This suggests a significant degree of thermal aggregation yielding polymers that were too large to enter the polyacrylamide stacking gel, which would also account for the lower TCA-soluble peptide concentrations (Table 3). Incubation resulted in virtually complete elimination of the principal bands in both the non-pressurized and pressurized homogenates, accompanied by the formation of lower-molecular-weight peptides. Table 2 shows pressure reduced proteolytic activity, but the higher activity recorded at $\mathrm{pH} 8$ than at $\mathrm{pH}$ 7 indicated that pressure did not inactivate the alkaline serine proteases.

No changes in the electrophoretic profiles for the enzyme extracts from the sardine and blue whiting were observed following high-pressure treatment (Fig. 7). The principal bands remained discernible and did not undergo any alterations in intensity, indicating that no pressure-induced rupture of the proteins took place. Forces that stabilize the quaternary structure of proteins may have been altered by the high-pressure processing; but if so, this was not accompanied by changes in molecular weight. This finding was in accordance with the results for proteolytic activity (Table 2), which remained practically unaltered, indicating that the proteases were highly resistant to high pressure.

\section{CONCLUSIONS}

Peak proteolytic activity was recorded at $55^{\circ} \mathrm{C}$ for both species, at an acid $\mathrm{pH}$ in the sardine and at an alkaline $\mathrm{pH}$ in the blue whiting; the predominant enzyme families involved being aspartic proteases in the case of the sardine, and alkaline serine proteases in the case of the blue whiting.

High pressure decreased proteolytic activity in the sardine muscle, especially at the peak activity $\mathrm{pH}$ and temperature, by reducing the activity of the aspartic proteases. Proteolytic activity in the pressurized blue whiting was barely affected under the peak activity conditions, but increased slightly at $35-50^{\circ} \mathrm{C}$ at the natural post-mortem muscle $\mathrm{pH}$. In this species high pressure gave rise to a small increase in serine and aspartic protease activity and to a decrease in cysteine protease activity.

Consequently, in view of the small direct effect of high pressure on the proteases in the conditions of this study, the changes in proteolytic activity that took place in the muscle can be attributed largely to the effects of pressure on other muscle components, in particular the myofibrillar proteins, the main substrate for enzymatic reactions. This finding agrees with the higher level of protein degradation observed on incubating the pressurized muscle and the low level of inactivation of the enzyme extracts on applying high pressure.

\section{ACKNOWLEDGMENTS}

This research was supported by Spain's Comisión Interministerial de Ciencia y Tecnología [Interministerial Science and Technology Board], mainly under project ALI AGL2000-1497. The authors thank the Comunidad de Madrid (CAM) [Autonomous Madrid Regional Government] for Ms. Hernández’s predoctoral fellowship.

\section{REFERENCES}

1. Jiang ST. Enzymes and their effects on seafood texture. In: Haard NF, Simpson BK, eds. Seafood Enzymes: Utilization and Influence on Postharvest Seafood Quality. Marcel Dekker, New York. 2000; 411-450.

2. Kubota M, Kinoshita M, Kubota S, Yamashita M, Toyohara H, Sakaguchi M. Possible implication of 
metalloproteinases in post-mortem tenderization of fish muscle. Fish. Sci. 2001; 67: 965-968.

3. An H, Weerasinghe V, Seymour TA, Morrissey MT. Cathepsin degradation of Pacific whiting surimi proteins. $J$. Food Sci. 1994; 59: 1013-1017, 1033.

4. Kinoshita M, Toyohara H, Shimizu Y. Purification and properties of a novel latent proteinase showing myosin heavy chain degrading activity from threadfin-bream muscle. J. Biochem. 1990; 107: 587-591.

5. Cao MJ, Jiang XJ, Zhong HC, Zhang ZJ, Su WJ. Degradation of myofibrillar proteins by a myofibril-bound serine proteinase in the skeletal muscle of crucian carp (Carasius auratus). Food Chem. 2006; 94: 7-13.

6. Ayensa MG, Montero MP, Borderías AJ, Hurtado JL. Influence of some protease inhibitors on gelation of squid muscle. J. Food Sci. 2002; 67: 1636-1641.

7. Park JW, Yongsawatdigul J, Kolbe E. Proteolysis and gelation of fish proteins under ohmic heating. In: Shahidi F, Ho CT, Chuyen N, eds. Process-induced Chemical Changes in Food. Plenum Press, New York. 1998; 25-34.

8. Sahin S, Sumnu G. Effects of microwave cooking on fish quality. Int. J. Food Properties. 2001; 4: 501-512.

9. Ashie INA, Simpson BK. Application of high hydrostatic pressure to control enzyme related fresh seafood texture deterioration. Food Res. Int. 1996; 29: 569-575.

10. Hurtado JL, Montero P, Borderías J, An H. Properties of proteolytic enzymes from muscle of octopus (Octopus vulgaris) and effects of high hydrostatic pressure. J. Food Sci. 2002; 67: 2555-2564.

11. Seyderhelm I, Boguslawski S, Michaelis G, Knorr D. Pressure induced inactivation of selected food enzymes. $J$. Food Sci. 1996; 61: 308-310.

12. Simpson BK. High pressure processing of fresh seafood. In: Shahidi F, Ho CT, Chuyen N, eds. Process-induced Chemical Changes in Food. Plenum Press, New York. 1998; 67-80.

13. Lakshmanan R, Patterson MF, Piggott JR. Effects of high pressure processing on proteolytic enzymes and proteins in cold-smoked salmon during refrigerated storage. Food Chem. 2005; 90: 541-548.

14. Hernández-Andrés A, Gómez-Guillén C, Montero P, PérezMateos M. Partial characterization of protease activity in squid (Todaropsis eblanae) mantle: modification by high pressure treatment. J. Food Sci. 2005; 70: C239-C245.

15. Angsupanich K, Ledward DA. High pressure treatment effects on cod (Gadus morhua) muscle. Food Chem. 1998; 63: 39-50.

16. Morrissey MT, Karaibrahimoglu Y, Sandhu J. Effect of high hydrostatic pressure on Pacific whiting surimi. In: Shahidi F, Ho CT, Chuyen N, eds. Process-induced Chemical Changes in Food. Plenum Press, New York. 1998; 57-65.

17. Vyncke W. pH of Fish Muscle: Comparison of Methods. Western European Fish Technologists' Association (WEFTA), Copenhagen, Denmark. 1981.

18. Gómez-Guillén MC, Batista I. Seasonal changes and preliminary characterization of cathepsin D-like activity in sardine (Sardina pilchardus) muscle. Int. J. Food Sci. Technol. 1997; 32: 255-260.

19. Homma N, Ikeuchi Y, Suzuki A. Levels of calpain and calpastatine in meat subjected to high pressure. Meat Sci. 1995; 41: 251-260.

20. Ohmori T, Shigehisa T, Taji S, Hayashi R. Biochemical effects of high hydrostatic-pressure on the lysosome and proteases involved in it. Biosci. Biotechol. Biochem. 1992; 56: $1285-1288$.

21. Homma N, Ikeuchi Y, Suzuki A. Effects of high pressure treatment on the proteolytic enzymes in meat. Meat Sci. 1994; 38: 219-228.

22. Jung S, de Lamballerie-Anton M, Ghoul M. Modifications of ultrastructure and myofibrillar proteins of post-rigor beef treated by high pressure. Lebensm. Wiss. Technol. 2000; 33: 313-319.

23. Chéret R, Delbarre-Ladrat C, de Lamballerie-Anton M, Verrez-Vagnis V. High-pressure effects on the proteolytic enzymes of sea bass (Dicentrarchus labrax L.) fillets. J. Agric. Food Chem. 2005; 53: 3969-3973.

24. Nielsen LB, Nielsen HH. Purification and characterization of cathepsin D from herring muscle (Clupea harengus). Comp. Biochem. Physiol. (Part B) Biochem. Mol. Biol. 2001; 128: 351-363.

25. Kubo T, Gerelt B, Han GD, Sugiyama T, Nishiumi T, Suzuki A. Changes in immunoelectron microscopic localization of cathepsin $\mathrm{D}$ in muscle induced by conditioning or high-pressure treatment. Meat Sci. 2002; 61: 415-418.

26. Fernández-Martín F, Pérez-Mateos M, Montero P. Effect of pressure/heat combinations on blue whiting (Micromesistius poutassou) washed mince: thermal and mechanical properties. J. Agric. Food Chem. 1998; 46: 3257-3264.

27. Benjakul S, Visessanguan W, Leelapongwattana K. Purification and characterization of heat-stable alkaline proteinase from bigeye snapper (Pricanthus macaracanthus) muscle. Comp. Biochem. Physiol. (Part B) Biochem. Mol. Biol. 2003; 134: 579-591.

Fig. 1 Proteolytic activity in the non-pressurized (NP) and pressurized (P) sardine (circles) and blue whiting (squares) muscle: (a) for the natural post-mortem muscle $\mathrm{pH}$ (pH 6 in the sardine, $\mathrm{pH} 7$ in the blue whiting) at different temperatures, (b) for different $\mathrm{pH}$ levels at the peak activity temperature $\left(55^{\circ} \mathrm{C}\right)$.

Fig. 2 Effect of protease inhibitors on proteolytic enzymes in the nonpressurized (NP) and pressurized (P) sardine (dots) and blue whiting (lines) muscle incubated at the peak activity temperature $\left(55^{\circ} \mathrm{C}\right)$ at (a) post-mortem muscle $\mathrm{pH}$ (pH 6 in the sardine, $\mathrm{pH} 7$ in the blue whiting) and at the peak activity $\mathrm{pH}$, (b) $\mathrm{pH} 3$ in the sardine and (c) $\mathrm{pH} 8$ in the blue whiting. For purposes of calculating the residual activity, the results obtained for a control (no inhibitor, incubation at the assay temperature) were taken as $100 \%$ proteolytic activity. EDTA, ethylenediaminetetraacetic acid; IA, iodoacetic acid; PMSF, phenylmethyl sulfonyl fluoride.

Fig. 3 Sodium dodecylsulfate-polyacrylamide gel electrophoresis results for the non-pressurized (NP) and pressurized (P) (a) sardine and (b) blue whiting muscle held at $7^{\circ} \mathrm{C}$ for 0,8 and $24 \mathrm{~h}$. Ac, actin; $\mathrm{H}$, high-molecular-weight standard; L, low-molecular-weight standard; MHC, myosin heavy chain.

Fig. 4 Sodium dodecylsulfate-polyacrylamide gel electrophoresis results for the non-pressurized (NP) and pressurized (P) sardine muscle incubated at (a) $40^{\circ} \mathrm{C}$ or (b) $55^{\circ} \mathrm{C}$ for 0,4 and $8 \mathrm{~h}$. Ac, actin; MHC, myosin heavy chain.

Fig. 5 Sodium dodecylsulfate-polyacrylamide gel electrophoresis results for the non-pressurized (NP) and pressurized (P) blue whiting muscle incubated at (a) $40^{\circ} \mathrm{C}$ or (b) $55^{\circ} \mathrm{C}$ for 0,4 and $8 \mathrm{~h}$. Ac, actin; MHC, myosin heavy chain.

Fig. 6 Sodium dodecylsulfate-polyacrylamide gel electrophoresis results for non-pressurized (NP) and pressurized (P) homogenates 
prepared from the sardine and blue whiting muscle at natural postmortem pH. (a) pH 6 in the sardine, (c) $\mathrm{pH} 7$ in the blue whiting; and at the peak activity $\mathrm{pH}$ (b) $\mathrm{pH} 3$ in the sardine, (d) $\mathrm{pH} 8$ in the blue whiting. n.i., no incubation; i., incubation at $55^{\circ} \mathrm{C}$ for $1 \mathrm{~h}$.

Fig. 7 Sodium dodecylsulfate-polyacrylamide gel results for nonpressurized (NP) and pressurized (P) enzyme extracts from the (a) sardine and (b) blue whiting. H, high-molecular-weight standard; L, low-molecular-weight standard. 
Table 1 Protein content ( $\mu \mathrm{g})$ per lane during sodium dodecylsulfate-polyacrylamide gel electrophoresis performed on the homogenates

\begin{tabular}{|c|c|c|c|c|c|c|}
\hline \multicolumn{2}{|l|}{ Sample } & \multicolumn{4}{|c|}{ Treatment } & \\
\hline & \multirow[t]{2}{*}{$\mathrm{pH}$} & \multicolumn{2}{|c|}{ Non-pressurized } & \multicolumn{2}{|c|}{ Pressurized } & \\
\hline & & n.i. & $55^{\circ} \mathrm{C} / 1 \mathrm{~h}$ & n.i. & $55^{\circ} \mathrm{C} / 1 \mathrm{~h}$ & \\
\hline Sardine & Muscle pH & 30 & 30 & 30 & 30 & \\
\hline \multirow[t]{2}{*}{ Blue whiting } & Muscle pH & 30 & 30 & 30 & 30 & \\
\hline & peak activity $\mathrm{pH}$ & & 78 & 18 & 18 & 9 \\
\hline
\end{tabular}

Homogenates from each species were prepared at post-mortem muscle $\mathrm{pH}(\mathrm{pH} 6$ for the sardine, $\mathrm{pH} 7$ for the blue whiting) and at the peak activity $\mathrm{pH}$ (pH 3 for the sardine, $\mathrm{pH} 8$ for the blue whiting).

n.i., no incubation and samples incubated at $55^{\circ} \mathrm{C}$ for $1 \mathrm{~h}$.

TCA-soluble peptides in the supernatant (after adding TCA to the homogenates and a centrifugation at $6.100 \mathrm{~g}$ at $7^{\circ} \mathrm{C}$ for $15 \mathrm{~min}$ ) were analyzed by the method of Bradford. 
Table 2 Proteolytic activity of the pressurized and non-pressurized homogenates and crude enzyme extracts from both species at the natural post-mortem muscle $\mathrm{pH}$ (pH 6 in the sardine, $\mathrm{pH} 7$ in the blue whiting) and at the peak activity $\mathrm{pH}$ (pH 3 in the sardine, $\mathrm{pH} 8$ in the blue whiting) at $55^{\circ} \mathrm{C}$

\begin{tabular}{|c|c|c|c|c|c|}
\hline \multicolumn{2}{|l|}{ Sample } & \multicolumn{4}{|l|}{ Treatment } \\
\hline & & \multicolumn{2}{|l|}{ Sardine } & \multicolumn{2}{|l|}{ Blue whiting } \\
\hline & & Non-pressurized & Pressurized & Non-pressurized & Pressurized \\
\hline Homogenates & Muscle $\mathrm{pH}$ & $1.74 \pm 0.13^{\mathrm{a}, \mathrm{x}}$ & $12.97 \pm 0.67^{\mathrm{b}, \mathrm{x}}$ & $7.89 \pm 0.77^{\mathrm{b}, \mathrm{x}}$ & $2.55 \pm 0.16^{\mathrm{a}, \mathrm{x}}$ \\
\hline \multirow[t]{2}{*}{ Enzyme extracts } & Muscle $\mathrm{pH}$ & $1.06 \pm 0.20^{\mathrm{a}, \mathrm{x}}$ & $0.94 \pm 0.18^{\mathrm{a}, \mathrm{x}}$ & $1.40 \pm 0.17^{\mathrm{a}, \mathrm{x}}$ & $1.97 \pm 0.35^{\mathrm{b}, \mathrm{x}}$ \\
\hline & Peak activity pH & $3.92 \pm 0.31^{\mathrm{b}, \mathrm{y}}$ & $3.26 \pm 0.036^{\mathrm{a}, \mathrm{y}}$ & $1.91 \pm 0.19^{\mathrm{b}, \mathrm{y}}$ & $1.54 \pm 0.15^{\mathrm{a}, \mathrm{y}}$ \\
\hline
\end{tabular}

For each specie, different letters $(\mathrm{a}, \mathrm{b})$ in the same file and in the same column $(\mathrm{x}, \mathrm{y})$, indicate significant differences $(P \leq 0.05)$.

Following the incubation, trichloroacetic acid was added to stop proteolysis, and then, the sample was. centrifuged at $6100 \times g$ for 15 min at $4{ }^{\circ} \mathrm{C}$. The content of soluble oligopeptides in the supernatant was analyzed by the method of Lowry et al. (28). Activity was expressed as $\mu$ moles of tyrosine released per gram of muscle per hour of incubation ( $\mu \mathrm{mol} \mathrm{Tyr} / \mathrm{g} / \mathrm{h})$. 
Table 3 Protein concentration (mg/mL of trichloroacetic acid-soluble peptides) in the supernatants from the sardine and blue whiting muscle homogenates prepared at the post-mortem muscle $\mathrm{pH}$ (pH 6 in the sardine, $\mathrm{pH} 7$ in the blue whiting) and at the peak activity $\mathrm{pH}$ (pH 3 in the sardine, $\mathrm{pH} 8$ in the blue whiting)

\begin{tabular}{|c|c|c|c|c|c|}
\hline & & \multicolumn{2}{|c|}{ Non-pressurized } & \multicolumn{2}{|c|}{ Pressurized } \\
\hline & & n.i. & $55^{\circ} \mathrm{C} / 1 \mathrm{~h}$ & n.i. & $55^{\circ} \mathrm{C} / 1 \mathrm{~h}$ \\
\hline \multirow[t]{2}{*}{ Sardine } & Muscle $\mathrm{pH}$ & 9.95 & 4.24 & 10.54 & 8.00 \\
\hline & Peak activity $\mathrm{pH}$ & 6.15 & 0.29 & 12.69 & 6.21 \\
\hline Blue whiting & Muscle pH & 9.31 & 9.20 & 5.73 & 4.30 \\
\hline
\end{tabular}

n.i. no incubation and samples incubated at $55^{\circ} \mathrm{C}$ for $1 \mathrm{~h}$.

Trichloroacetic acid (TCA)-soluble peptides in the supernatant (after adding TCA to the homogenates and a centrifugation at $6100 \times g$ at $7^{\circ} \mathrm{C}$ for $15 \mathrm{~min}$ ) were analyzed by the method of Bradford. 